\title{
Limites e equívocos do conceito de acumulação fordista: desenvolvimento das forças produtivas e perpetuação das formas de produção arcaicas ${ }^{1}$
}

\author{
Ronaldo Vielmi Fortes ${ }^{2}$
}

\section{Resumo:}

O artigo apresenta a crítica ao conceito de acumulação taylorista/fordista, demonstrando as distorções provocadas por tal noção na compreensão da dinâmica econômica transcorrida ao longo do século XX, particularmente nos EUA. Por meio desta crítica, busca-se demonstrar como tal abordagem dos processos de acumulação cria vícios conceituais que dificultam a análise dos processos de acumulação em vigor na atualidade.

Palavras-chave: acumulação capitalista; acumulação taylorista-fordista; maquinaria.

\section{Limits and misconceptions of the Fordist accumulation concept: development of the productive forces and perpetuation of archaic forms of production}

\begin{abstract}
:
The article presents a critique of the Taylorist/Fordist accumulation concept, demonstrating the distortions provoked by this notion in the understanding of the economic dynamics that occurred throughout the 2oth century, particularly in the USA. Through this critique it tries to demonstrate how such an approach of the processes of accumulation creates conceptual vices that make difficult the analysis of the processes of accumulation at the present time.
\end{abstract}

Key words: capitalist accumulation; Taylorist-Fordist accumulation; machinery.

Tornou-se comum referir à economia capitalista do século XX como um processo de acumulação caracterizado fundamentalmente pela organização fordista da produção. Tal designação é ampliada a tal ponto que chega, na concepção de vários sociólogos, economistas e pesquisadores em geral, à compreensão e determinação do assim chamado ciclo de acumulação fordista/taylorista como a forma explicativa de toda a dinâmica da economia no século em questão. A "linha de montagem", a

\footnotetext{
${ }^{1} \mathrm{O}$ artigo compõe resultados parciais da pesquisa de pós-doutorado realizada junto do Departamento de Filosofia da Fafich-UFMG.

2 Professor Adjunto da Universidade Federal de Juiz de Fora (UFJF). E-mail: rvielmi@yahoo.com.br.
} 
obsessiva forma de controle dos movimentos das atividades dos trabalhadores postas em ação pela organização científica do trabalho, a relação salário/capital característica da época funcionam como padrões analíticos que descrevem desde a forma da organização das unidades produtivas, passando pelas tendências sociais mais marcantes (a chamada sociedade de consumo), até as causas fundamentais do crescimento econômico do período designado como Golden age (1945-70).

Obviamente, não se trata aqui de negar o fenômeno da organização científica do trabalho tão bem - e insistentemente - posto em evidência pela literatura sociológica, porém cabe tecer apontamentos acerca da exacerbação de fatos característicos de certos ramos de produção ao patamar de uma formação geral, válida universalmente para todos os processos econômicos e sociais ocorridos ao longo do século XX. Em diversos autores, o assim chamado taylorismo/fordismo termina por se constituir na chave analítica hegemônica que abre as portas para a compreensão dos meandros da sociedade capitalista do século em questão. Nessa medida, torna-se também parâmetro e critério decisivo para a explicação das transformações do "mundo do trabalho" da sociabilidade posterior, do assim chamado capitalismo do século XXI. Basta para demonstrar nossa última asserção listar as variantes designativas que buscam determinar os fenômenos atuais quase sempre erigidos em contraposição à formação anterior, como é o caso de designações como o "pós-fordismo", o "toyotismo" como substituto do fordismo, ou expressões como modo de "acumulação flexível" em contraposição à "inflexibilidade" ou "rigidez" da acumulação fordista etc.

Talvez não fosse de todo um exagero afirmar que os sociólogos mais arraigados em tal abordagem terminem por se manterem obcecados por uma contra-apolegética do sistema fundada em jargões voluntaristas, incorrendo em um exame da realidade que tende a omitir a investigação pormenorizada das relações sociais concretamente postas, direcionando seus estudos apenas a alguns aspectos bem específicos do fenômeno da organização do trabalho, particularmente àqueles que comprovam suas hipóteses. Desse modo, as formas mais extremas destas abordagens, procedem à inversão da ordem de determinações ao sustentar que tais fenômenos não constituem o resultado das determinações de fundo postas pelas tendências da dinâmica econômica, mas constituem as expressões fundamentais do sistema de produção ou mesmo as determinantes essenciais do ciclo de acumulação capitalista do período. O que deve ser explicado é alçado à função de critério explicativo, negligenciando desse modo o fato - empírico e não conceitual - de que tais formas organizativas do trabalho não foram modos universais da gestão do trabalho, antes pelo 
contrário, foram na realidade formas particulares circunscritas a ramos muito específicos da produção industrial.

\section{Taylorismo como uma forma desdobrada da manufatura}

Chama a atenção o fato de parte dessa literatura reivindicar para si a condição de ser de afiliação marxista, vislumbrando no pensamento de Karl Marx as bases da abordagem acerca da forma prevalente da acumulação capitalista. É o caso, por exemplo, de Benjamin Coriat investigador francês que produziu livros influentes sobre o tema na década de 1970 - que em sua obra Science, technique et capital, identifica nas reflexões de Marx em torno da manufatura do século XVIII e início do século XIX os princípios fundamentais do taylorismo:

Tudo o que Marx anuncia no que concerne às características especificamente capitalistas do processo de trabalho (parcelização das tarefas, incorporação do saber técnico na máquina, caráter despótico da direção) Taylor em relação ao processo de trabalho, o realiza, ou mais exatamente dá a ele uma esfera de extensão que não possuía até então. O interesse excepcional que se apresenta em Taylor reside no fato de que ele é a expressão consciente, concentrada e sistemática dos interesses do capital em um momento estratégico de sua história. (CORIAT, 1976, p. 133)

De fato, as linhas características essenciais da manufatura, tal como descritas pelo pensador alemão, guardam fortes semelhanças com as linhas mestras que se pode encontrar na organização taylorista do trabalho. Para efeitos de cotejamentos, lembremos que Marx descreve a manufatura demonstrando suas caracterizações mais gerais:

Ao combinar ofícios originalmente dispersos, tal manufatura reduz a separação espacial entre as fases particulares de produção do artigo. O tempo de sua passagem de um estágio para outro é reduzido, assim como o trabalho que medeia essa passagem. Em comparação com o artesanato obtém-se, com isso, um acréscimo de força produtiva, sendo tal acréscimo derivado, na verdade, do caráter cooperativo geral da manufatura. Por outro lado, seu princípio peculiar da divisão de trabalho provoca um isolamento das diferentes fases de produção, que, como diversos outros trabalhos parciais artes anais, se autonomizam mutuamente. Estabelecer e manter a conexão entre as funções isoladas exige o transporte constante do artigo de uma mão para outra e de um processo para outro. Do ponto de vista da grande indústria, isso se revela uma limitação característica, dispendiosa e imanente ao princípio da manufatura. (MARX, 2013, p. 418)

A produção diversificada culmina na ação final de montagem das diversas componentes que provêm das mais distintas localidades 
produtivas. $\mathrm{O}$ aspecto relevante é o fato de cada produção culminar em seu desdobramento na divisão de tarefas, cada vez mais depurada e específica, levando a produção à desqualificação técnica do trabalhador na medida em que reduz sua atividade à ação simples de movimentos repetitivos. $\mathrm{O}$ taylorismo, e nesse sentido deve-se dar razão a Coriat, é a organização mais sistematizada, mais obcessivamente interessada na administração em cada detalhe dos movimentos do trabalhador, expressa a intensificação e radicalização do cálculo detalhado do processo produtivo. Mas, e é esse aspecto o relevante de nossa observação crítica, o taylorismo constitui uma forma mais desenvolvida da manufatura, da produção com base na divisão de tarefas no interior do processo produtivo.

Coriat negligencia o fato de as descrições feitas por Marx acerca da manufatura se encontrarem no interior de uma discussão mais ampla, na qual o autor considera o movimento que leva da manufatura ao advento da maquinaria na chamada "grande indústria". Esse aspecto pode ser ressaltado na sequência da citação acima reproduzida, precisamente na última frase que encerra o parágrafo em questão: "Do ponto de vista da grande indústria, isso se revela uma limitação característica, dispendiosa e imanente ao princípio da manufatura" (MARX, 2013, p. 418). O encerramento do parágrafo não é fortuito, pois Marx em suas reflexões propõe destacar os desdobramentos da forma da acumulação capitalista presente já no século XIX, dando destaque aos limites da forma de organização do trabalho própria da manufatura e à necessidade tendencial - de superação de seus limites, precisamente para responder à dinâmica crescente da acumulação do capital.
A base do velho método, a mera exploração brutal do material de trabalho, acompanhada em maior ou menor medida de uma divisão do trabalho sistematicamente desenvolvida, já não bastava a um mercado em expansão e à concorrência cada vez mais acirrada entre os capitalistas. Era chegada a hora da maquinaria. A máquina decisivamente revolucionária, que se apodera indistintamente de todos os inumeráveis ramos dessa esfera da produção, como as confecções de trajes finos, a alfaiataria, a fabricação de sapatos, a costura, a chapelaria etc., é a máquina de costura. (MARX, 2013, p. 542)

Marx identifica como linha tendencial dos processos de acumulação capitalista o desenvolvimento das forças produtivas, caracterizada fundamentalmente pelo advento da maquinaria, que suplanta em grande parte o que foi a característica fundamental da forma de produção até então predominante (em particular no século XVIII), ou seja, a manufatura. A maquinaria é determinada como o elemento ulterior da dinâmica histórica do desdobramento da linha tendencial do capitalismo. Conforme diz Marx, a necessidade de ampliação de mercado e os limites 
das formas anteriores da produção impõem o desenvolvimento dos aparatos técnicos de produção.

O princípio da grande indústria, a saber, o de dissolver cada processo de produção propriamente dito em seus elementos constitutivos, e, antes de tudo, fazê-lo sem nenhuma consideração para com a mão humana, criou a mais moderna ciência da tecnologia. As formas variegadas, aparentemente desconexas e ossificadas do processo social de produção se dissolveram, de acordo com o efeito útil almejado, nas aplicações conscientemente planificadas e sistematicamente particularizadas das ciências naturais. A tecnologia descobriu as poucas formas fundamentais do movimento, sob as quais transcorre necessariamente, apesar da diversidade dos instrumentos utilizados, toda ação produtiva do corpo humano, exatamente do mesmo modo como a mecânica não deixa que a maior complexidade da maquinaria a faça perder de vista a repetição constante das potências mecânicas simples. A indústria moderna jamais considera nem trata como definitiva a forma existente de um processo de produção. Sua base técnica é, por isso, revolucionária, ao passo que a de todos os modos de produção anteriores era essencialmente conservadora. (MARX, 2013, p. 306)

$\mathrm{O}$ uso da maquinaria figura como o fator preponderante da forma mais avançada da acumulação capitalista. Conforme salienta Marx, no capítulo 23 do livro I, de $O$ capital, a acumulação capitalista se caracteriza fundamentalmente pelo aumento da composição orgânica do capital, ou seja, o aumento proporcional dos gastos com o capital constante em detrimento do capital variável. $\mathrm{O}$ advento da máquina e seu predomínio no processo produtivo possibilita ao capitalista alcançar um maior controle sobre o capital constante, possibilitando um aumento da velocidade de produção e, inclusive, permite transpor de maneira bem-sucedida aos limites naturais (corporais) do elemento força de trabalho. A partir desse ponto, a produção não se encontra mais restringida pelos limites da força física do trabalhador, mas submete esse último às exigências do mecanismo, esse assume agora o papel, para usar a expressão do próprio autor, de "apêndice da máquina”.

Nesse sentido, não há dúvidas, que para o pensador alemão:

Por meio da maquinaria, de processos químicos e outros métodos, ela revoluciona continuamente, com a base técnica da produção, as funções dos trabalhadores e as combinações sociais do processo de trabalho. Desse modo, ela revoluciona de modo igualmente constante a divisão do trabalho no interior da sociedade e não cessa de lançar massas de capital e massas de trabalhadores de um ramo de produção a outro. A natureza da grande indústria condiciona, assim, a variação do trabalho, a fluidez da função, a mobilidade pluridimensional do trabalhador. Por outro lado, ela reproduz, em sua forma 
capitalista, a velha divisão do trabalho com suas particularidades ossificadas. Vimos como essa contradição absoluta suprime toda tranquilidade, solidez e segurança na condição de vida do trabalhador, a quem ela ameaça constantemente com privar-lhe, juntamente com o meio de trabalho, de seu meio de subsistência'": como, juntamente com sua função parcial, ela torna supérfluo o próprio trabalhador; como essa contradição desencadeia um rito sacrificial ininterrupto da classe trabalhadora, o desperdício mais exorbitante de forças de trabalho e as devastações da anarquia social. (MARX, 2013, pp. 556-7)

Há dois aspectos importantes a serem ressaltados nessa citação. O primeiro destaca o constante revolucionamento da produção com base no desenvolvimento da tecnologia; entretanto, em contraposição, o segundo aspecto não deixa de observar certa continuidade da "velha forma" da "divisão do trabalho com suas particularidades ossificadas". Nesse sentido, por mais que a linha tendencial da dinâmica da acumulação capitalista seja descrita em termos gerais pelo desenvolvimento e incremento da produtividade posta em movimento pela maquinaria, não se deixa de observar que as condições de trabalho tendem a se deteriorar, levando o trabalhador à situação de subalternidade no processo produtivo e, mesmo, à preservação de velhas formas de exploração - voltaremos a esse ponto mais à frente.

Voltando novamente a atenção para Coriat, vale dizer que suas afirmações são escolhas muito seletivas das considerações de Marx, fato que o leva à afirmação completamente contrária ao que diz o filósofo alemão, identificando na manufatura o padrão da acumulação capitalista do século XX, enquanto Marx identifica sua suplantação já no século XIX com o advento da maquinaria (cf. MORAES NETTO, 1991, pp. 24-33).

As origens de tais entendimentos - das tendências teóricas fundamentadas no conceito de acumulação fordista/taylorista -, como o que narramos a partir do exemplo de Coriat, podem ser bem datadas na história do pensamento sociológico e econômico. Muitos autores são unanimes em localizar na escola francesa dos regulacionistas as origens de tal concepção - da qual inclusive o sociólogo francês aqui citado faz parte. De certo modo o marco inaugural dessa escola de pensamento pode ser identificado na obra de Aglieta, Crise e regulação do capitalismo e teve contribuições importantes nas obras de outros regulacionistas como Alain Lipietz e Robert Boyer.

Sem nos delongarmos muito sobre os aspectos teóricos dessa escola de pensamento, importa apenas focalizar os elementos mais gerais da tese. É Lipietz quem nos ajuda a estabelecer as linhas gerais da noção de "acumulação taylorista" e do conceito de "acumulação fordista". No século $\mathrm{XX}$, segundo o autor, podemos identificar ao menos dois momentos bem 
característicos da acumulação americana. No primeiro deles, ocorre durante o período entre as duas grandes guerras:

o desenvolvimento do taylorismo e dos embriões do fordismo provoca a primeira grande onda de acumulação intensiva. A produtividade cresce a uma taxa de $6 \%$ ao ano (o triplo da tendência do século XIX), mas o poder de compra continua em seu momento medíocre. Essa compressão, altamente favorável à taxa de lucro, (...) provoca uma crise sem precedentes de superprodução: a crise dos anos 19303. (LIPIETZ, 1984, p. 703)

Um pouco mais tarde, após a segunda Guerra Mundial, a consolidação do chamado "fordismo" permite estabilizar oferta e demanda, permitindo o equilíbrio da economia e viabilizando seu crescimento. Tem lugar, segundo o autor, uma nova fase da acumulação intensiva:

que perdurou, por sua vez, por vinte anos, durante os quais a produtividade aumentou consideravelmente, (...) mas desta vez o aumento do poder de compra dos empregados (produtivos e improdutivos) acompanhou quase exatamente o aumento da produtividade. (LIPIETZ, 1984, p. 704)

As teses da escola regulacionista são bastante controversas, para muitos autores eivada de erros técnicos, de dados e de compreensão em relação aos fundamentos básicos dos teóricos clássicos da economia4. Não cabe nesse artigo o aprofundamento da crítica de tais problemas. Importa apenas destacar a gênese das expressões, apontando para pelo menos dois problemas: primeiro, são esses autores que tomam a particularidade da organização de produção taylorista e fordista e o alçam ao patamar de critério da dinâmica da acumulação; segundo, negligenciam a perpetuação das características da manufatura tanto no taylorismo como no fordismo, deixando completamente de lado a questão das tendências da acumulação capitalista com base na maquinaria, já presentes ao longo do século XIX.

\section{A influência de Harry Bravermann e os vícios de leitura}

Sem dúvida a influência das ideias centrais dos autores que compõem escola regulacionista se faz sentir ao longo do século XX e ainda hoje - por vias mais indiretas do que diretas - fornece a base e o ponto de

3 Acerca dessa tese vale reproduzir aqui, en passant, a crítica de Duménil e Lévy (1991, p. 3): "Lipietz não indica qual país ele considera. Se esta análise diz respeito aos Estados Unidos, o que parece necessário para explicar a origem da crise, essa caracterização do período está errada. A década de 1920 nos Estados Unidos não é marcada por um forte crescimento da produtividade do trabalho; a taxa de lucro é baixa em comparação com seu valor antes da primeira guerra mundial ou após a segunda; a relação entre o consumo final e o PIB é alta”.

4 A literatura que realiza a crítica dos regulacionistas é ampla e diversificada. Não nos cabe nesse sentido um aprofundamento na crítica dessa escola de pensamento. Remetemos os interessados à crítica de Brenner e Glick (1989, pp. 89-131). 
partida para diversas concepções sociológicas que tratam do problema das formas específicas do processo de acumulação capitalista e do papel que as transformações do trabalho desempenha no interior desses processos. Talvez o caso mais exemplar nesse sentido seja a obra de Harry Bravermann, Trabalho e capital monopolista, que mesmo sem fazer remissões diretas a essa escola e à tese aqui em questão, contribuiu de maneira decisiva para estabelecer o lugar central das reflexões sobre a dinâmica econômica do século XX, como fundamentalmente fordista/taylorista. A análise crítica bem detalhada dos princípios mais gerais do taylorismo e do fordismo, com forte ênfase no predomínio do advento da organização científica do trabalho, contribuiu de maneira efetiva para a difusão da ideia do predomínio desta forma de organização da produção ao longo do século XX. Nesse sentido, essa obra também agiu como a matriz de diversas concepções posteriores.

Entretanto, não se poderia deixar de vislumbrar na obra de Bravermann, em seu emblemático capítulo 9, intitulado "Maquinaria”, as advertências do autor que sugerem distinções significativas entre a mecanização da indústria e o uso ainda centrado na utilização da força de trabalho humana típica da manufatura.

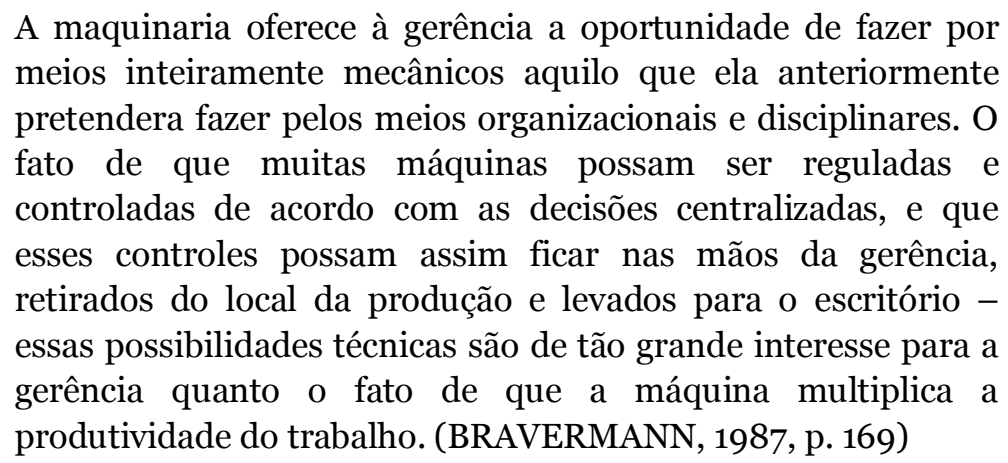

Poucas páginas adiante, Bravermann dá claro testemunho de que a linha de montagem é uma forma arcaica e não a expressão das formas mais avançadas da produção, ao mesmo tempo em que estabelece, em linhas bem gerais, as razões para sua vigência:
A principal vantagem da linha de montagem industrial é o controle que ela permite sobre o ritmo de trabalho, e como tal ela é inexcedivelmente útil para os proprietários e gerentes, cujos interesses estão em desavença com os de seus trabalhadores. De um ponto de vista tecnológico, é extraordinariamente primitivo e pouco tem a ver com a "tecnologia da máquina moderna". Contudo, em tais relíquias bárbaras acha-se o assento do "conhecimento científico" e a base da tecnologia. (BRAVERMANN, 1987, p. 200)

A novidade consiste, assim nos parece, em as "relíquias bárbaras" incorporarem elementos do "conhecimento científico", mas não serem em si mesmos exemplares puros das formas mais avançadas da produção. 
Com base nessas considerações seria um equívoco tomar tais formas específicas próprias da assim chamada "linha de montagem" como o padrão, ou mesmo, como a forma predominante da produção característica do século XX. As "relíquias bárbaras" convivem - e são viabilizadas - pelas formas mais aprimoradas da "tecnologia da máquina moderna”. O próprio autor adverte, no capítulo em questão, que na produção caracterizada pelo fluxo contínuo - como é o caso da indústria química, metalúrgica, têxtil etc. - o processo adotado é fortemente mecanizado (cf. BRAVERMANN, 1987, pp. 162-4), por conseguinte, não guarda nenhuma semelhança com as formas típicas do fordismo/taylorismo.

A despeito desse significativo capítulo onde o autor dá mostras claras de que um processo paralelo importante ocorria em seu tempo, a ênfase de seu livro recaí sobre os aspectos da organização científica do trabalho condizentes com o taylorismo/fordismo. Se se tomar seus estudos como uma narrativa que visa destrinchar esse fenômeno específico do processo de produção - fordismo/taylorismo - não há dúvidas de que suas considerações são bastante contributivas. Entretanto, a linha de desenvolvimento de sua obra, ainda que faça advertências sobre formas distintas da produção, tem toda sua base assentada sobre a descrição da OCT, limitando as considerações sobre os outros processos a um único capítulo de seu livro. Ao referir, mas não tratar em detalhes as tendências significativas à mecanização da indústria em seu tempo, de algum modo suas considerações terminam por se ater com maiores detalhes aos princípios do fordismo/taylorismo, restringindo desse modo o amplo horizonte da totalidade dinâmica dos processos econômicos e de produção vigentes na época.

Porém, a desatenção aos aspectos postos em evidência no capítulo aqui referido possui outras motivações. Nesse sentido, não podem ser atribuídas unilateralmente a supostas insuficiências do livro de Bravermann. Esquecer ou simplesmente tomar tais considerações como fortuitas ou meras observações pontuais mostra o cerne das tendências que predominaram ao longo do século XX nas assim chamadas sociologias de esquerda. As simplificações, quase sempre de caráter voluntarista, em grande medida se prestam a enfatizar o caráter tortuoso da exploração da classe trabalhadora no decorrer dos processos da produção industrial americana. Fato que deveras esteve presente, porém não se pode descurar de uma ampla série de outros fatores que determinaram de maneira efetiva o processo de acumulação do século em questão. 


\section{A produção industrial americana e a especificidade do fordismo}

Para o propósito de nossa discussão importa ressaltar: se em dados ramos industriais tal lógica da produção manufatureira foi viabilizada, em outros setores se assistiu exatamente ao contrário dessa tendência. Bastaria referir o setor têxtil americano - e isso já no século XIX na Inglaterra, onde este setor da economia aparecia como o lócus da alta tecnologia - para destacar o elevado nível de utilização tecnológica, implicando a maior composição técnica do capital. Mesmo em outros setores, como o das grandes corporações de produção alimentícia, tabaco ou no setor das indústrias químicas e farmacêuticas, o uso da maquinaria aparece como fenômeno de significativa relevância. Nesse sentido, setores importantes da economia americana, ou mesmo da inglesa e da alemã, apresentaram uma dinâmica inversa ao que aconteceu na indústria automobilística. Neles não vemos sequer sombras de uma baixa composição orgânica do capital, pelo contrário, no século XIX, em particular nos EUA, verificamos essa outra tendência decisiva do setor produtivo, qual seja: a mecanização.

Citemos, a propósito, dois exemplos. A indústria do cigarro apresentava em seu processo produtivo antes de sua mecanização a produtividade média de dois cigarros/minuto por trabalhador - em casos excepcionais trabalhadores mais experientes alcançavam a marca de quatro por minuto. Em 1880, James Albert Bonsack inventou a Automated cigarette rolling machine e a produção mecanizada alcançou o volume de produção de 120 mil cigarros em 10 horas, ou seja, 200 cigarros por minuto (cf. CHANDLER/HIKINO, 1990, p. 63). Em suma, a máquina produzia o equivalente ao que 3 mil dos trabalhadores mais rápidos e experientes eram capazes de produzir em uma jornada de mesmo período - ou o equivalente a seis mil dos trabalhadores médios. Essa base tecnológica permitiu inclusive o advento da monopolização do setor, ao eliminar pequenos produtores e ao alcançar forte vantagem competitiva sobre os concorrentes.

Outro caso demonstra a evolução tecnológica na indústria de alimentos, essa também de relevante papel na economia americana do final do século XIX.

A revolução da embalagem teve outro impulso em 1883, quando os irmãos Norton, Edwin e OW, construíram a primeira fábrica de linha automática com máquinas capazes de soldar latas a uma taxa de 50 por minuto, junto com outras máquinas que adicionavam partes superiores e inferiores à lata a uma taxa de 2.500 a 4.400 unidades por hora. Com base nessa nova tecnologia, Gail Borden rapidamente expandiu suas instalações para envasar leite e sua organização para comercializá-lo. Os Dorrances da Filadélfia fizeram o mesmo com os produtos da 
Campbell Soup. O mesmo aconteceu com Henry John Heinz em Pittsburgh, com suas "57 variedades" de picles, molhos e outros produtos. Libby, McNeill \& Libby criaram uma empresa similar que produzia carne enlatada em Chicago. (CHANDLER; HIKINO, 1990, p. 64)

As inovações que se processaram nesse campo se espalharam para outros ramos, como por exemplo, na fabricação de cerveja, na destilação do uísque, refino de açúcar, de óleo de sementes de algodão, ácido sulfúrico, assim como outros produtos químicos 5 . No que tange às inovações presentes nesse intervalo de tempo, ao analisar o desenvolvimento das indústrias americanas, Chandler e Hikino enfatizam que

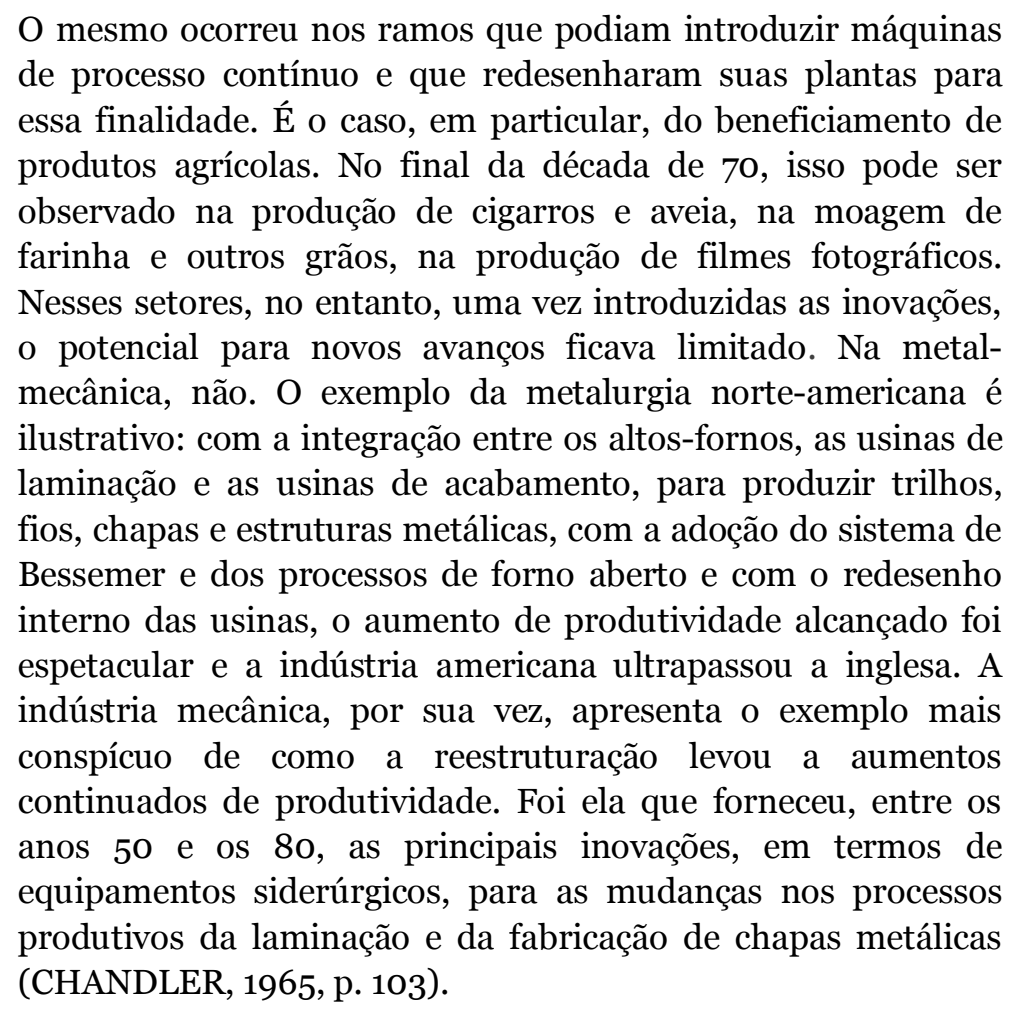

A tabela abaixo oferece uma rápida visão dos vários setores que compunham a acumulação na economia americana ao longo do século XX. Por meio dela se pode perceber que o sistema do fordismo não é a única linha adotada no sistema de produção.

\footnotetext{
5 No mesmo livro de Chandler e Hikino (1990), encontramos um instrutivo capítulo Expanding organizational capabilities: investment abroad and product diversification in machinery, no qual são tratados em detalhes o uso da maquinaria nos diversos ramos da produção manufatureira americana.
} 
As quinze maiores empresas americanas - 1907, 1948 e 1959

\begin{tabular}{|c|l|c|l|c|l|c|}
\hline \multirow{2}{*}{ Class. } & \multicolumn{2}{|c|}{1907} & \multicolumn{2}{c|}{1948} & \multicolumn{2}{c|}{ 1959 } \\
\cline { 2 - 7 } & \multicolumn{1}{|c|}{ indústria } & setor & \multicolumn{1}{|c|}{ indústria } & setor & \multicolumn{1}{c|}{ indústria } & Setor \\
\hline 1 & U.S. Steel & Steel & Standard Oil (N.J.) & Oil & $\begin{array}{l}\text { Standard Oil } \\
\text { (N.J.) }\end{array}$ & Oil \\
\hline 2 & Standard Oil & Oil & General Motors & $\begin{array}{c}\text { Auto/Power } \\
\text { Machinery }\end{array}$ & General Motors & $\begin{array}{c}\text { Auto/Power } \\
\text { Machinery }\end{array}$ \\
\hline 3 & $\begin{array}{l}\text { American } \\
\text { Tobacco }\end{array}$ & Agricultural & U.S. Steel & Steel & U.S. Steel & Steel \\
\hline 4 & $\begin{array}{l}\text { International } \\
\text { Harvester }\end{array}$ & Machinery & $\begin{array}{l}\text { Standard Oil } \\
\text { (Ind.) }\end{array}$ & Oil & Ford Motor & $\begin{array}{c}\text { Auto/Power } \\
\text { Machinery }\end{array}$ \\
\hline 5 & $\begin{array}{l}\text { Amalgamatec } \\
\text { Anaconda) }\end{array}$ & Nonferrous & Socony-Vacuum & Oil & Gulf Oil & Oil \\
\hline 6 & Central Leather & Agricultural & Texaco & Oil & Texaco & Oil \\
\hline 7 & Pulmann & Machinery & Gulf Oil & Oil & Socony-Vacuum & Oil \\
\hline 8 & Armour \& Co. & Agricultural & Du Pont & Chemical & Du Pont & Chemical \\
\hline 9 & $\begin{array}{l}\text { American Sugar } \\
\text { Refining }\end{array}$ & Agricultural & General Eletric & Eletric & $\begin{array}{l}\text { Standard Oil } \\
\text { (Ind.) }\end{array}$ & Oil \\
\hline 10 & U.S. Rubber & Rubber & Ford Motor & $\begin{array}{l}\text { Auto/Power } \\
\text { Machinery }\end{array}$ & $\begin{array}{l}\text { Standart Oil } \\
\text { (Calif.) }\end{array}$ & Oil \\
\hline 11 & $\begin{array}{l}\text { American } \\
\text { Smelting \& } \\
\text { Refining }\end{array}$ & Nonferrous & $\begin{array}{l}\text { Standart Oil } \\
\text { (Calif.) }\end{array}$ & Oil & General Eletric & Eletric \\
\hline 12 & Singer Mfg. Co. & Machinery & Bethlehem Steel & Steel & Bethlehem Steel & Steel \\
\hline 13 & Swift \& Co. & Agricultural & Sears, Roebuck & $\begin{array}{l}\text { Mass } \\
\text { Mercahndisi } \\
\text { ng }\end{array}$ & Sheel Oil & Oil \\
\hline 14 & Pittsburg Coal & Nonferrous & Union Carbide & Chemical & Union Carbide & Chemical \\
\hline
\end{tabular}

Fonte: Elaboração com autor, com base em CHANDLER (1973, pp. 5-6).

Os dois caminhos - maquinaria ou uso intensivo da força de trabalho - mostram-se em curso ao longo deste período histórico. Nesse sentido, é preciso indagar sobre as motivações que levam à escolha de um ou de outro caminho. Considerações elucidativas são apresentadas por David Landes em livro Prometeu desacorrentado, onde assevera que a opção pelo uso de mão de obra ou pela adoção da maquinaria envolve decisões que respondem ao contexto da diversidade econômica do ramo de negócios onde se encontra inserido - poderíamos até mesmo dizer, além de decisões de âmbito estritamente tecnológico, a alternativa contábil é de grande relevância.

Quão importante foi a mecanização do transporte e da manipulação dentro das fábricas? A resposta varia conforme a natureza das empresas, em alguns processos, o manuseio representa mais de $85 \%$ do custo do produto final; em indústrias leves como a de produtos têxteis, representa muito pouco. Além disso, os grandes guindastes de cavalete ou elevadores móveis não são, em si, uma garantia de economia. Em muitos casos, as empresas eram providas de equipamentos grandes ou complexos demais para o trabalho exigido. E, algumas vezes, a mão-de-obra era tão barata que as máquinas constituíam um luxo. É muito fácil confundir a parafernália da modernidade com eficiência. (LANDES, 2005, p. 314) 
Em termos mais claros, a opção pelo uso de mão de obra ou pela adoção da maquinaria envolve decisões que respondem ao contexto da diversidade econômica do ramo de negócios e produção onde se encontra inserido. Compete também para essas decisões os custos do uso de mãode-obra comparativamente à implementação da maquinaria. Conforme destaca Landes, nem sempre a "parafernália da modernidade" pode ser entendida como "eficiência", sendo mais razoável em certos casos o uso da mão-de-obra barata o meio mais racional em termos de custos. Reportando-se a fatos, o autor demonstra que o setor da indústria cuja principal atividade é a de montagem - a indústria "que abrange campos como a construção mecânica a engenharia, a fabricação de roupas e calçados e as indústrias de construção" - caracterizou-se pelo elevado número de trabalhadores na produção. Contudo, esse aspecto não elimina a razão inversa que leva ao outro lado dessas escolhas: a indústria de transformação, ou seja, aquela cuja atividade consiste na conversão "de determinado conjunto de matérias-primas em outra forma" (LANDES, 2005, p. 312) - têxteis, químicas, metalúrgicas, produção de vidros, refino petróleo, o processamento industrial de alimentos etc. - assumiu o caminho inverso, adotou de maneira intensiva a mecanização da produção ${ }^{6}$.

A rica e detalhada apresentação dos caminhos concretos assumidos pelos vários ramos da indústria, analisados por Landes, tendem a insistir muito mais no critério técnico específico de cada área, o que sem dúvida se mostra como um aspecto de relevância considerável nas escolhas assumidas. No entanto, ao que o autor salienta poderíamos acrescentar que o contexto histórico e a particularidade de cada país importam tanto quanto, ou mais ainda, no conjunto das decisões. Em outros termos, falar da elevada disponibilidade de mão-de-obra barata como alternativa mais viável não explicita as razões da sua existência em uma dada sociedade.

Se voltarmos nossa atenção novamente à indústria automotiva americana, as observações de Moraes Neto (1991) a respeito da mesma questão trazem com maiores detalhes os elementos postos pela condição social e econômica americana que levam ao surgimento do taylorismo e a seu desdobramento posterior no fordismo. Voltando-se aos problemas das condições que propiciaram o advento do fordismo/taylorismo, o autor do livro Marx, Taylor, Ford: as forças produtivas em discussão, tece apontamentos importantes para a compreensão das condições específicas da economia americana que viabilizaram tal fenômeno:

\footnotetext{
${ }^{6}$ Para se ter uma ideia da proporção de empregados em ramos distintos da produção, enquanto em 1925 a GM empregava 83.278 trabalhadores, a Du Pont possuía cerca de 14.000 empregados. Os ativos das corporações eram, respectivamente, US\$ 703,8 milhões e US\$ 305,7 milhões (CHANDLER, 1973, p. 50).
} 
Trata-se da necessidade imperiosa do aumento de produção, que, através de tentativas sucessivas, vai conformando a linha de montagem. Por um lado, a luta pelo mercado potencialmente fabuloso do novo produto, o automóvel, dentro dos marcos do capitalismo monopolista, não permitia a evolução lenta das escalas de produção, impondo-se desde logo a necessidade da grande empresa, e por outro não existia qualquer conhecimento prévio da "ciência da tecnologia" que pudesse se incorporar à produção do novo produto. (MORAES NETO, 1991, p. 60)

Desse modo, ao menos dois fatores estritamente vinculados um ou outro se apresentam como decisivos. $\mathrm{O}$ crescente mercado da indústria automotiva exigia o aumento da produtividade, mas ao mesmo tempo o desenvolvimento da tecnologia não havia ainda desenvolvido suficientemente os mecanismos aptos a serem empregados de maneira vantajosa nessa atividade. Além disso, por ser uma produção de produtos finais, que, por sua situação de relação direta com o consumidor, deveria atender diretamente ao mercado, tal condição impõe a necessidade de mudanças constantes em seus produtos. A especificidade desse ramo da atividade econômica fazia com que a mecanização viesse a ser tornar obsoleta em pouco tempo, tornando dispendiosa a troca constante da maquinaria e mais racional do ponto de custos a utilização de mão-deobra, cuja versatilidade implica em menos dispêndios no processo de adaptação às novas necessidades (cf. MORAES NETO, 1991, pp. 60-1).

Desse modo no caso a indústria automobilística americana o pano de fundo sobre o qual se assenta a organização da produção é a disponibilidade de um grande contingente de indivíduos compondo o exército industrial de reserva. Seja pela substituição de mão-de-obra em dados setores da economia, seja pelas fortes ondas de migração ocorridas ao longo do século $\mathrm{XX}^{7}$; ambos os fatores favoreceram muito a persistência de uma baixa composição orgânica do capital nesse setor em particular. Taylor, com base na lógica da divisão do trabalho, ou seja, sob os auspícios dos princípios mais básicos da produção manufatureira, foi capaz de colocar à disposição da indústria um enorme contingente de trabalhadores não qualificados.

O processo de acumulação capitalista ocorre ao final do século XIX e início do século XX, ou seja, o assim chamado taylorismo/fordismo surge mediante as condições de possibilidade postas por um processo que lhe é

\footnotetext{
7 Estima-se que ao longo do século XIX, ocorreram duas fortes ondas imigratórias nos EUA. A primeira, que vai do período de 1815 até a guerra civil americana constitui uma mão de obra sobretudo alocada na agricultura, com uma estimativa de 5 milhões de imigrantes. Na segunda onda de imigração, entre 1880 e 1915, os EUA receberam cerca de 12 milhões de imigrantes de diversas localidades (cf. CORIAT, 1982, pp. 25-9). Esse contingente de imigrantes favorece muito a ampliação do exército industrial de reserva necessário ao ciclo de acumulação americana ocorrido nos últimos anos do séc. XIX e início do séc. XX.
} 
anterior. O taylorismo, forma mais desenvolvida e aprimorada da manufatura, somente pôde se desenvolver dadas as pré-condições favoráveis anteriores. Ele não forjou a enorme disponibilidade de força de trabalho, soube, e esse é seu mérito, tornar a enorme quantidade de trabalhadores desqualificados, úteis para determinados ramos da produção industrial.

O importante a ser ressaltado quanto a esses apontamentos aqui apresentados é a possibilidade de ambas as opções - a intensificação da manufatura ou a maquinaria - mostrarem-se possíveis em um mesmo contexto histórico. De fato, processos arcaicos de produção podem conviver com as técnicas produtivas mais avançadas. Primeiro pela disponibilidade de força de trabalho provocada pela substituição de trabalhadores pelas máquinas. Tal substituição, ao desocupar mão-de-obra de ramos específicos do setor produtivo, disponibiliza força de trabalho para outros ramos da produção além de permitir o rebaixamento geral dos salários em função do excesso de oferta de mão-de-obra, viabilizando o aumento do lucro das empresas dado a redução de custos com salários. Nesse sentido, mesmo em ramos da indústria ou da atividade econômica em que o avanço tecnológico não se faz presente, a menor composição orgânica do capital pode assim ser contemplada com uma margem maior de lucros. Desse modo, o advento de novas tecnologias em determinados ramos da produção industrial pode favorecer a permanência e mostrar-se eficaz em outros ramos das formas mais arcaicas da organização e das tecnologias produtivas.

Em seu livro Economia política e capitalismo Maurice Dobb explicita a possibilidade dessa coexistência, ao observar que, uma vez reduzido o preço dos salários em função da intensificação de sua produtividade e do predomínio do mais-valor relativo (maquinaria), o "barateamento da força de trabalho" leva, por um lado, ao aumento da "composição orgânica do capital", porém permite igualmente "retardar o processo de mudanças técnicas, tornando mais uma vez os métodos técnicos primitivos mais lucrativos" (DOBB, 1978, pp. 95-6).

No que tange aos processos ocorridos nos EUA, se em dados ramos industriais tal lógica da produção manufatureira se viu viabilizada, em outros setores assistiu-se exatamente ao contrário dessa tendência. Entretanto, o movimento tendencial é dado pela mecanização dos processos produtivos, esse é o ponto que queremos sustentar. O processo de acumulação americano não tem início com o taylorismo, pelo contrário o advento do taylorismo se assenta sobre condições anteriores, postas já nas últimas três décadas do século XIX, momento decisivo que caracteriza em termos bem claros e evidentes empiricamente os passos iniciais da 
pujança da economia americana. Esta tem sua base nessas décadas e se desdobra de maneira vigorosa ao longo do século posterior.

Portanto, se tivermos que responder à difícil questão sobre qual é o processo cuja preponderância determina com maior decisibilidade a dinâmica da acumulação capitalista de dado período, não hesitaríamos em identificar nos processos tecnologicamente mais avançados a primazia das tendências da acumulação. Ainda que o mais avançado conviva com o primitivo, a linha tendencial é dada por esse primeiro - voltaremos a esse problema mais à frente. Isso não significa, cabe insistir, que em dados ramos da produção a acumulação possa, por dado período, ocorrer por meio das formas arcaicas de produção, como no caso da prevalência da manufatura no fordismo - porém, de modo algum como a forma única, nem mesmo como a forma prevalente.

Em apoio ao que aqui se afirma não precisamos nos fiar apenas em Karl Marx, basta lembrar outro economista importante, John Hobson, que em seu instrutivo estudo A evolução do capitalismo moderno: um estudo da produção mecanizada estabelece acerca da acumulação do capital em vigor já em pleno século XIX:

\begin{abstract}
A maquinaria empregada na manufatura e no transporte tem tendência niveladora, que favorece diretamente a expansão da área de competição. À medida que a ampliação do conhecimento coloca cada parte do mundo industrial mais intimamente en rapport ao resto, os métodos de manufatura ${ }^{8}$, mais recentes e melhores, vão sendo adotados com mais rapidez e eficácia. Dessa forma, em toda produção onde uma parte cada vez menor depende da perícia dos operários, e cada vez mais da natureza da maquinaria, toda modificação que dá maior proeminência a esta tende a nivelar o custo de produção em diferentes países, e facilita assim a concorrência efetiva. (HOBSON, 1983, p. 112)
\end{abstract}

Ainda que os dados ora apresentados não possam ser de todo conclusivos para sustentar essa tese, cremos que apresentam elementos suficientes para colocar dúvidas sobre a posição contrária, segundo a qual, a forma da gestão fordista do trabalho explica o que foi o capitalismo do século XX. A inversão nos parece evidente. Ao invés de explicar o motivo pelo qual a forma da organização da linha de montagem se desenvolveu particularmente nas indústrias de montagem tais como a automobilísticas, da produção de eletrodomésticos etc., generaliza-se essa forma de organização a todo o setor industrial, interpretando de modo bem peculiar - pelo recurso da redução, simplificação e generalização - o movimento tendencial mais geral da acumulação do período em questão. A negligência

8 Em inglês: manufacture (HOBSON, 1897, p. 99), o termo em inglês não se reporta diretamente à manufatura tal como o emprega Marx, mas à produção industrial em geral. 
a outros elementos tão ou mais decisivos que esse critério fica patente nesse procedimento.

\section{Sobre os pressupostos do processo de acumulação americano}

A persistência em olhar para os fenômenos econômicos e sociais por meio do metro crítico do conceito parametrizador do "fordismo" tende a levar à desconsideração de aspectos relevantes das bases da dinâmica do capitalismo do terceiro quarto do século XIX e do início do século XX. O surgimento do trabalho coletivo e da grande indústria não se restringem ao campo da organização do trabalho ou ao específico critério tecnológico do processo de produção propriamente dito, mas implica o surgimento e a criação de condições outras, mais amplas e diversas, que eleva a complexidade do sistema produtivo em geral. Nesse sentido, a advertência necessária de ser feita é que a acumulação americana não tem início com o chamado fordismo/taylorismo, mas é oriunda e viabilizada por précondições bem anteriores, iniciadas nas décadas finais do século XIX nos EUA, de modo relevante na forma da organização de suas corporações industriais.

A exemplaridade do caso americano ocupa o centro dessa discussão, pois é a partir dela que surge a tese da acumulação fordista. Contudo, a história econômica americana mostra um caminho bem distinto:

A verdadeira natureza do grande capital americano, no entanto, reside no fato de ter-se apoiado na fusão entre o capital industrial e o capital bancário, sob a égide de uma "classe financeira geral", que promoveu a conglomeração e a diversificação das atividades produtivas fundamentais. A força expansiva do grande capital americano durante um século decorre assim, em última instância, não de uma pretensa superioridade tecnológica originária de seu sistema manufatureiro (que não era tão grande no início), nem da morfologia mais flexível da grande corporação americana (que todos acabaram copiando), nem, muito menos, de eventuais políticas agressivas (de corte imperialista clássico) de seu capital financeiro (que, quando existiram, não tiveram significado relevante), mas em seu gigantesco potencial de acumulação e em sua capacidade invulgar de unificar os mercados (internamente, primeiro, externamente, depois), resultantes ambos do poder do grande capital e de sua classe financeira. (TEIXEIRA, 2000, p. 158)

Para lançarmos mão novamente dos estudos de John Hobson - sem que isso signifique uma afiliação contumaz a suas ideias ${ }^{9}$ - que descrevem

\footnotetext{
9 Como bem destaca Maria da Conceição Tavares no prefácio que escreve à edição do livro de Hobson, o economista inglês tinha fortes ligações com o socialismo fabiano, o que o distancia em certa medida das prerrogativas revolucionárias advogadas pelos marxistas.
} 
de maneira precisa os processos que tem início nos EUA nas décadas finais do século XIX, podemos acrescentar:

Os limites reais da concentração do capital e do trabalho em empresas isoladas, à diferença do que acontece com unidades fabris isoladas, não se devem, em medida significativa, a considerações de caráter técnico, mas de administração e mercado. Por essa razão, uma proporção maior das mentes mais capazes, empenhadas na vida empresarial, direciona-se para a experimentação e para a descoberta de métodos administrativos, inclusive organização empresarial e finanças, com o duplo propósito de realizar grandes economias de custos da oferta e, assim, monopolizar ou controlar mercados, a fim de impedir que os ganhos passem para o consumidor, em virtude da concorrência entre produtores. (HOBSON, 1983, p. 106)

Hobson escreve seu livro em meio a um processo que se desenrolava e foi capaz nessa medida de acompanhar de perto as transformações e a particularidade do processo de acumulação americano ${ }^{10}$. Mais tarde, com o processo já estabelecido, outros autores chegam em suas investigações aos mesmos resultados, e acrescentam mais dados ainda, que confirmam o decorrer histórico das linhas tendenciais já evidenciadas por Hobson. É o caso da tão bem analisada e posta como núcleo determinante da especificidade da forma nascente do capitalismo americano caracterizada como "revolução gerencial", investigada com grande acuidade por Alfred Chandler. A criação de um núcleo de trabalhadores altamente especializados e tecnicamente instruídos foi elemento decisivo para a criação das bases do processo de acumulação americano que vigorou no século $\mathrm{XX}$, e, vale acrescentar, que conduziu esta nação a condição de império, cuja hegemonia se desenvolveu tanto no plano político quanto econômico, suplantando a hegemonia inglesa do século XIX.

O primeiro aspecto a ressaltar é a nova forma da organização das indústrias americanas, que se constituem já no século XIX como grandes corporações que dominam sob forma de oligopólios ramos inteiros da economia americana. A origem desse processo pode ser determinada nas corporações ligadas às estradas de ferro. As grandes ferrovias americanas modificaram de maneira radical tanto a produção como a distribuição de produtos. Elevou também o tamanho das empresas impondo um grau de complexidade muito maior em sua organização, fenômeno que forjou o advento de uma nova classe de trabalhadores altamente especializados, responsáveis por gerir e alargar todo o processo produtivo, comercial e

10 Vale lembrar que o livro recebeu pelos menos duas edições revisadas. A primeira publicação ocorreu no ano de 1894, sendo que na segunda (1906) o autor revisa o texto original acrescentando contribuições provenientes de Marx e Sombart. Na revisão de 1916, o autor acrescenta ao texto reflexões sobre a experiência e o impacto da I Guerra Mundial. 
financeiro. Essas profundas modificações nas corporações americanas foram caracterizadas por Alfred Chandler como a "revolução gerencial"11.

Os empreendimentos ferroviários americanos aliados ao crescimento da comunicação (telégrafos) permitiram, em primeiro lugar, a integração econômica do país criando um mercado interno favorável ao desenvolvimento de sua economia. Tal crescimento potencializou de maneira inédita um vasto setor da economia, seja o setor industrial, de comércio e mesmo financeiro. Na indústria,

permitiu o encontro entre o vapor, o carvão mineral, o ferro, a construção civil (pela exigência de obras de infraestrutura, como pontes e terminais urbanos) e o estado (como vetor de demanda); ela pressupõe um novo sistema de comunicações, que viria a surgir com o telégrafo; ela impulsiona o sistema fabril não apenas pela demanda que exerce, mas oferecendo segurança e rapidez nos transportes e comunicações, e, acima de tudo, um modelo de organização empresarial que iria revolucionar o velho sistema produtivo. (TEIXEIRA, 1999, p. 163)

No que tange à criação do sistema financeiro:

A operação dessas empresas apresentava requerimentos financeiros maciços, o que levou ao surgimento dos bancos de investimento, bem como à centralização e institucionalização do mercado financeiro em Nova York, diversificando-se as modalidades operacionais; sociedades por ações, títulos hipotecários, lançamento de debêntures, tudo passou a fazer parte do cardápio das novas instituições. A função financeira dentro da empresa também se especializou, com o surgimento do comptroller, tornando mais complexa a divisão do trabalho no seu interior. (TEIXEIRA, 1999, pp. 163-4)

Enfim, nesse fim de século ocorreu a assim chamada "revolução na distribuição" e a "revolução na produção", que implicou a criação dos alicerces necessários para a ampliação do mercado interno nos EUA. Conforme salientam Chandler e Hikino, autores do livro Scale and scope, "entre 1850 e 1880 a rede de transporte e de comunicação estabeleceram a base tecnológica e organizacional para a exploração da economia de escala e escopo no processo de produção e distribuição" (CHANDLER; HIKINO, 1990, p. 58). Esses desdobramentos foram os responsáveis pelo curso inicial da dinâmica americana, criaram as condições originárias para 0 decurso de desenvolvimento posterior. O importante de destacar é a maior complexidade das grandes empresas americanas, que diversificam suas ações, englobando de maneira definitiva tanto o processo de produção, de distribuição - por meio de uma estrutura mais complexa da organização

${ }^{11}$ Chandler analisa todo esse processo com maiores detalhes em seu livro The visible hand: managerial revolution in American business (1977). 
empresarial - assim como aprimorou e estreitou os laços de suas alianças necessárias com o setor financeiro.

A esse propósito é interessante lembrarmos novamente John Hobson, pois este já no decorrer do século XIX observa com acuidade esses elementos presentes na dinâmica econômica da acumulação americana. Conforme ressalta Maria da Conceição Tavares ao apresentar o importante de livro do economista inglês:

Hobson não se engana sobre a verdadeira natureza do grande capital americano. Ele tem claro que, se bem as ferrovias e a monopolização da agricultura e do comércio que acompanharam a expansão ferroviária sejam elementos decisivos do processo de constituição do grande capital americano, este se desenvolve a partir daí com apoio na fusão de interesses da grande indústria com o capital bancário, sob a égide de uma "classe financeira geral" que promove a conglomeração e a diversificação das atividades produtivas fundamentais. Assim, quando as ferrovias desaparecem como elemento de expansão, e são substituídas por um novo sistema de transporte automobilístico, é no monopólio do petróleo e na criação de um espaço metropolitano que a nova indústria automobilística iria se afirmar como uma grande indústria, destinada a converter-se, juntamente com a de material elétrico, no setor que lidera o crescimento industrial da "nova era", bem como a expansão internacional após a Segunda Guerra Mundial. É a força do grande capital e da classe financeira americana que determina a sua expansão e diferenciação, e não a superioridade tecnológica inicial do sistema manufatureiro americano, como querem vários autores que atribuem ao "progresso técnico" o papel desencarnado de Deus ex-machina. (TAVARES in HOBSON, 1984, p. XXI)

Novamente insistimos, não se trata apenas das possibilidades tecnológicas desenvolvidas, nem mesmo da característica própria da organização do trabalho da indústria automobilística. A novidade da dinâmica da acumulação capitalista americana consiste na forma particular endógena do capitalismo forjado nos anos finais do século XIX e plenamente desenvolvido no século XX, com base na aliança inusitada portanto específica do processo americano - entre o capital industrial e o capital financeiro. A posterior predominância da indústria automobilística, juntamente com as indústrias petroquímicas, de material elétrico etc. assentou-se sobre a estrutura forjada anteriormente, fruto da aliança entre o grande capital e as grandes corporações americanas.

O que queremos mostrar com tais considerações é que muito antes das estratégias postas por Ford ${ }^{12}$ na organização de suas empresas, as

12 A nós parece também estranho essa insistência no fordismo, uma vez que do ponto de vista da organização empresarial e da relativa grandeza das empresas no interior da 
linhas gerais de tal constituição industrial já estavam dadas na economia americana. Nesse sentido, por mais expressivas que tenham sido as formas da organização fordista, não é ela de modo algum a fonte originária e inspiradora das novas formas da gestão empresarial; na realidade, sua exemplaridade funciona muito mais como a aplicação bem-sucedida das linhas tendências que se hegemonizavam nas formas da gestão das empresas na América.

Ainda que contra argumentem dizendo que o conceito de acumulação fordista contempla tudo o que acima indicamos, o fato é que na maior parte dos casos põe-se em evidência a dimensão particular da organização do trabalho, negligenciando o complexo de múltiplos fatores dessa dinâmica. A acumulação capitalista é nessa medida, "síntese de múltiplas determinações"13, cujo processo se move pondo ênfase ora em um fator específico ora em outro fator, ou mesmo em um conjunto de fatores que se potencializam reciprocamente; somente a análise particular dos casos pode decidir sobre o fator ou fatores que predominaram em dada época, ou por que não dizer, em dados ramos da produção. No entanto, isso não significa a inexistência de determinações tendenciais, que sempre, em última instância terminam por se fazer presentes decurso histórico das nações. É o caso da tendência apontada por Marx acerca do crescente aumento da composição orgânica do capital e do desenvolvimento das forças produtivas.

\section{A crise da década de 1970 e os limites da linha de montagem}

A crise do final da década de 1960 e início de 1970 põe fim a um longo ciclo de crescimento da economia mundial. De lá para cá assistimos àquilo que Robert Brenner caracterizou de "longa estagnação". Por mais que no decorrer dos últimos 45 anos possamos ter assistido picos muito particulares de recuperação da economia - o chamado boom das ".com" na década de 1990 - todo esse período pode ser entendido como as décadas em que não se assistiu mais ao recrudescimento da acumulação nos mesmos padrões do período pós-guerra, do chamado golden age (cf. BRENNER, 2006, cap. 13). Não é o caso aqui de discutir em detalhes toda a problemática tratada por Brenner em seu livro, mas demonstrar as consequências dessa crise para a aqui debatida organização fordista da produção, pois é particularmente a partir dessa crise que ela apresenta traços evidentes de esgotamento.

indústria automobilística, a GM já havia, em 1920, ultrapassado a Ford, tanto em termos qualitativos quanto quantitativos.

${ }_{13}$ Uso aqui uma famosa frase de Marx em um contexto próximo ao usado por ele, porém não equivalente. 
É interessante observar que, de acordo com Brenner (2006, cap. 8), um dos fatores de maior relevância para a eclosão da crise consiste no fim das vantagens competitivas da indústria americana frente à capacidade produtiva e tecnológica de outros países ${ }^{14}$. Tal como demonstra o autor, após a segunda guerra mundial, os EUA conquistaram grandes vantagens tecnológicas frente às outras nações do mundo, que se encontravam em grande parte destruídas em função da guerra. A vantagem tecnológica e produtiva americana, sem dúvida, criou condições favoráveis para permitir às suas corporações uma zona de conforto, na medida em que sua hegemonia nos mercados internacionais não esteve ameaçada por um período considerável: do pós-guerra ao início da década de 1970.

O setor automobilístico é bem emblemático nesse sentido. A manufatura (o fordismo/taylorismo) pôde perdurar como processo de produção eficaz justamente no período de desequilíbrio entre as nações, no momento em que a produção americana efetivamente se punha na condição de mais avançada e superior aos processos de outros países. Mostrou sua eficácia nos períodos em que o desequilíbrio entre as nações pendia favoravelmente ao predomínio do modo americano da produção industrial. $\mathrm{O}$ avanço tecnológico japonês e alemão a partir da década de 1960, o recrudescimento da competição entre estes países e os EUA, forçam modificações significativas no processo produtivo e mesmo na organização das empresas. Em um primeiro momento, ainda limitadas à certa dimensão manufatureira também característica da forma da organização toyotista - alguns autores argumentam que o toyotismo surge a partir da adaptação do fordismo às condições específicas da economia e da sociedade japonesa (Cf. GOUNET, 2002, p. 25) ${ }^{15}$ - as corporações americanas assumem, sob pressão, o modelo de produção da nação nipônica, procurando adaptar-se às vantagens conquistadas pelo modelo japonês. Ocorre, contudo, uma via de mão dupla. A pressão exercida contra a economia americana, retroage sobre sua própria fonte - sobre o Japão, sobre a Alemanha - impondo a elas igualmente a constante busca de vantagens competitivas, alcançada dentre outros fatores também pelo desenvolvimento e adoção de novas tecnologias. A partir desse período é notório o uso cada vez mais intensivo da automação, em que a própria atividade da montagem sofre o forte impacto do uso da tecnologia em detrimento do uso da força de trabalho.

14 Tal fenômeno não se restringiu ao setor automobilístico. Na produção dos eletroeletrônicos, por exemplo, o Japão já se apresentava como uma ameaça à indústria americana nos idos da década de 1960. Sobre esse desenvolvimento ver o livro de Chandler, O século eletrônico (2002).

15 Sobre a organização dos trabalhadores no interior do sistema produtivo e sobre as vantagens do sistema Toyota, ver também pp. 30-34. 
A velha forma da produção manufatureira do fordismo/taylorismo, no novo contexto que entra em curso, dá claras evidências de seus limites no plano do novo acirramento dos processos competitivos internacionais. Não apenas o processo de produção precisou mudar, mas também toda a relação trabalhista, sua legislação, organização sindical etc. sofrem mudanças significativas. $\mathrm{O}$ ataque frontal às organizações da classe trabalhadora, a retirada de direitos conquistados por meio de anos de lutas, são os elementos mais perceptíveis da luta capital/trabalho. Mas outras medidas também marcam os novos rumos assumidos. Na organização das empresas assiste-se ao abandono da verticalização da cadeia produtiva, em prol da horizontalização da produção. Isso significa o advento e forte predomínio da terceirização da produção. As grandes corporações adotam o novo modelo deixando para trás a estrutura horizontal anterior, que visava todo o controle da cadeia produtiva, buscando alcançar vantagens competitivas por meio do controle das matérias-primas básicas de seu ramo industrial.

Em síntese, a coexistência de métodos avançados de produção com o que aqui temos designado como a perpetuação aprimorada das formas "arcaicas" do processo produtivo (taylorismo-fordismo) pôde perdurar por um período considerável - de 1945 a 70 -, porém com o passar do tempo a tendência de desenvolvimento de forças produtivas se impõe, levando as formas menos avançadas inexoravelmente à supressão, ou à condição de subalternidade periférica na dinâmica global de produção. Dados históricos demonstram esses aspectos postos pelas tendências ao recrudescimento contínuo da composição orgânica do capital. Desse modo, no caso da própria indústria automotiva onde por um largo período de tempo predominou no processo da montagem os traços mais característicos da produção manufatureira, o acirramento da competição oriunda do advento da maior eficiência produtiva japonesa e alemã, forçam os antagonistas a abandonar a velha forma da organização da produção em busca de vantagens competitivas, levando-os ao uso de tecnologias mais avançadas.

\section{Lições para os dias de hoje: China e Brasil}

Não poderíamos encerrar essa discussão sem ao menos apontar, ainda que de maneira provisória, as consequências e lições que poderíamos extrair dos acontecimentos anteriores para a época atual. Tomando por base a ideia da coexistência das formas arcaicas da produção e do processo de acumulação capitalistas com as formas mais avançadas da dinâmica econômica da acumulação, é possível vislumbrar em nossos dias dois extremos em ação. De um lado, para usarmos a fórmula genérica bastante comum em nossos tempos, a "precarização do trabalho", que 
implica em termos gerais a retomada da primazia do valor absoluto (aumento da jornada de trabalho, redução salários, destruição de direitos, formas precárias da empregabilidade etc.), e de outro lado, o que hoje se acostumou chamar de advento da "indústria 4.0" (internet das coisas, robótica, nanotecnologia etc.). Esse último, dada a elevada capacitação técnica e científica requerida tende a se concentrar nos países centrais, ainda que nesses países o fenômeno da precarização do trabalho também se encontre presente de forma significativa. Nos países periféricos é evidente o predomínio da precarização, enquanto as grandes inovações da ciência e da tecnologia, quando ocorrem, acontecem apenas de maneira tópica e restrita a âmbitos bem delimitados da ciência e da tecnologia.

Desse modo, nos dias atuais, a mesma questão se mantém: o que leva a optar pela intensificação do uso da mão de obra ou pela adoção das tecnologias de vanguarda disponíveis? Pensemos o caso da Apple, empresa ícone americana, seja na dimensão expressiva que ela assume no mercado, seja pela alta tecnologia dos produtos por ela desenvolvidos. Sua produção é fundamentalmente realizada pelos "arcaicos" processos da manufatura, a "relíquia" viva e operante da linha de montagem da Foxconn. A empresa tailandesa responsável por toda a produção da icônica corporação americana se vale dos processos mais rudimentares da produção - sistema de dormitórios ${ }^{16}$ e o taylorismo -, associados à baixa remuneração dos trabalhadores e à fragilidade das condições legais destes na China - onde a empresa localiza grande parte de sua produção.

A tecnologia da automação poderia substituir perfeitamente a velha linha de montagem fordista. Em certa medida, podemos dizer que o âmbito que leva a esta decisão encontra-se fundamentalmente alicerçado no cálculo contábil: salários baixos, leis trabalhistas menos rigorosas, a farta mão-de-obra disponíveli7. Não apenas essas vantagens se fazem presentes nesse caso. Não poderíamos deixar de referir os relatos dos próprios diretores da Apple, no qual relacionam dentre outras vantagens comparativas de se produzir na China e não nos EUA, a versatilidade e flexibilidade da produção. Conforme já escrevi em outra oportunidade (FORTES, 2018, p. 269) os executivos da Apple

\footnotetext{
16 "Sistema de dormitório chinês": os trabalhadores dormem na própria empresa, situação que facilita a convocação de trabalhadores para prestar horas extras até mesmo em horários inadequados (trabalho de madrugada ou extensão excessiva da jornada de trabalho).

17 Estima-se que na China o montante de trabalhadores disponíveis no setor da indústria e a construção civil girava em torno de 160 milhões em 2001 - "65-70 milhões nas cidades e 90 milhões nas zonas rurais". Número superior ao da OCDE cujo censo indicava 131 milhões. "No setor industrial urbano, ele ultrapassa o da União Europeia e dos EUA tomados conjuntamente (64 milhões). Ele eclipsa também os recursos de mão-de-obra mobilizados na indústria de outros grandes países em desenvolvimento: 9 milhões no Brasil, 13 milhões na Indonésia, 25 milhões na Îndia” (LEMOINE, 2003, p. 50).
} 
lembram que não foi difícil para Apple organizar sua produção na China, haja vista que na montagem e preparação para a produção do iPhone a empresa, por meio da Foxconn, foi capaz de recrutar certa de 8.700 engenheiros industriais e mais de 200 mil trabalhadores em apenas 15 dias; enquanto, por estimativa, essa mesma proporção de mobilização de mão-deobra em um país como os EUA levaria pelo menos 9 meses para se efetivar. Outra vantagem, segundo um ex-executivo da firma de Cupertino, consiste no fato de toda a cadeia de suprimentos necessários se localizar no interior da própria China: "Você precisa de mil juntas de borracha? Basta bater na fábrica ao lado. Precisa de um milhão de parafusos? A fábrica para isso está a um quarteirão de distância. Quer que o parafuso seja um pouco diferente? Isso leva apenas três horas para ser feito." (DUHIGG; BRAKSHER, 2012).

Em contrapartida, temos de salientar que o desenvolvimento chinês há muito deixou de assumir essa feição exclusiva da produção por via das aqui designadas formas arcaicas da organização do trabalho. Embora ainda esteja presente o uso das velhas formas, a China abdicou da alternativa unilateral de se desenvolver segundo o modelo da fábrica do mundo. Diante da elevação de nível da produção, fruto quase inevitável do desenvolvimento econômico alcançado pelo país, a China mudou o foco de seu desenvolvimento fazendo investimentos no campo da alta tecnologia e da ciência. O novo projeto chinês coloca como prerrogativa a ser realizada a autossuficiência tecnológica. Com investimentos massivos na área de pesquisa e desenvolvimento (P\&D) o crescimento desde o ano de 1999 girou em torno de $20 \%$ ao ano. Em números isso significa aproximadamente um investimento de US\$ 233 bilhões, cifra que corresponde a $20 \%$ dos investimentos mundiais em P\&D. Não por acaso, no ano de 2018 os cientistas chineses das áreas de ciências e das engenharias, suplantaram o total de publicações dos cientistas americanos. Suas publicações, antes irrelevantes para o mundo, são nos dias de hoje frequentemente citadas por pesquisadores de todo o mundo (SEGAL, 2018).

Obviamente tais direcionamentos e avanços na área da ciência e tecnologia não levam a sanar as contradições da sociedade chinesa, ao contrário as agudizam. Ao eliminar o aparato industrial ultrapassado, em particular daquelas empresas que fabricavam produtos de má qualidade ou mesmo que produziam produtos falsificados, acabou gerando, por conseguinte o aumento do desemprego no país. Tais medidas também não suprimem as desigualdades econômicas existentes no país caracterizadas por disparidades exorbitantes no desenvolvimento entre diferentes regiões. Greves frequentes e longas se desenvolveram nas últimas décadas mostrando de maneira evidente as dimensões das contradições entre capital e trabalho presentes na sociedade chinesas (NABUCO, 2012). 
O exemplo chinês mostra de maneira clara a segunda via tendencial de desenvolvimento tecnológico presente em nossos dias. Trata-se do domínio e da aplicação de tecnologia de ponta, cujo pressuposto implica também a formação de uma mão de obra altamente qualificada para o exercício dessas atividades. O que se produz nessas áreas é obviamente de grande impacto nos processos atuais da acumulação capitalista, porém dado o caráter recente de tais empreendimentos e desenvolvimento ainda é difícil dimensionar sua relevância. A pergunta que deve ser feita é qual o lócus e o quantum da participação que cada uma dessas tendências desempenha na acumulação capitalista hodierna? Porém, se as considerações de Marx ainda são válidas para o capital do nosso século, a preponderância recai sobre o desenvolvimento das forças produtivas, isto é, na acumulação capitalista as formas mais avançadas da tecnologia de produção ditam os rumos mais decisivos da sua dinâmica. É o lócus onde a produção de mais-valor se dá de forma mais intensificada e efetiva.

Decerto não seria tarefa árdua localizar a posição do Brasil no decurso atual dos desdobramentos das economias nacionais. Das duas tendências, obviamente a da precarização do trabalho é a que se põe de fato em andamento no país. Tal aspecto nos põe diante de uma questão de grande relevância. Observa-se entre os investigadores a maior atenção no problema da "precarização", enquanto nesses mesmos autores vemos apenas lineamentos bem gerais acerca da "indústria 4.0". Não se poderia dizer que tal prevalência se deve à limitação das metodologias e teorias que norteiam suas pesquisas, ou que tais limites estejam relacionados à condição subjetiva dos investigadores; trata-se muito mais do fato de a efetividade dos processos de produção brasileiros realizarem tão somente uma faceta particular das tendências atuais: as formas rudimentares associadas à formas mais perversas da precarização. Em outras palavras, o alto desenvolvimento tecnológico não se concretiza na terra brasilis.

Em certa medida, tomando por base tal ausência nos países da periferia, podemos nos perguntar se a ênfase unilateral nas denúncias da precarização por parte dos sociólogos e economistas não é consequência exatamente da ausência desses progressos. A compreensão termina por se limitar à constatação do fenômeno, atribuindo à voracidade do grande capital, ao desespero pelo aumento da lucratividade por parte dos empresários, o achaque violento da classe trabalhadora. Em última instância, se agarram às fileiras da defesa dos direitos e da luta pelos salários, sem serem capazes de estabelecer as linhas mais gerais e preponderantes das tendências hoje em curso na acumulação capitalista. Veem, nessa medida, o fenômeno, mas se curvam diante da impossibilidade objetiva - e subjetiva - de explicitar o conjunto das determinações e tendências hoje em curso na economia mundial. Por 
outro lado, vislumbram ao longe com os olhos assustados, ofuscados pela ignorância e confusão, o horizonte que se descortina além das fronteiras nacionais.

Que me seja permitido então a partir da próxima citação fazer uma provocação, isentando o autor das linhas que se seguem de qualquer responsabilidade sobre o sentido e a intenção em que aqui se tomam suas palavras:

\begin{abstract}
Especialistas - ora sem objeto real, ora sem condição subjetiva de isenção - os economistas alemães só praticam a miudagem do que em outra parte fora ciência, ou seja, só viveram o simulacro e a decadência, sem nunca ter experimentado o ascenso teórico da economia política, situados que sempre estiveram em momentos de sociabilidade adversos ao exercício genuíno dessa disciplina, ou dito ao revés, não contaram jamais com as condicionantes positivas ou propícias, soa a perspectiva da lógica societária do capital, à criação e ao desenvolvimento dessa forma de saber. (CHASIN, 2009, p. 118)
\end{abstract}

Chasin se reporta às considerações críticas de Marx acerca dos economistas alemães de seu tempo. O caráter de desenvolvimento tardio dos estados que compunham a Alemanha no período faz com que seus teóricos da economia acolham apenas os reflexos das transformações e dinâmicas concretas que aconteciam nos países vizinhos, em especial, na Inglaterra. Porém, apenas assimilam essa ciência já em seu período de decadência, quando esta deixou suas feições revolucionárias e científicas, próprias do momento de construção da sociabilidade do capital, quando essa ainda lutava contra as velhas formas do feudalismo, rumo à edificação de um mundo novo.

Parafraseando as palavras acima transcritas, poderíamos então modificar o sentido originário, desse modo: "Especialistas - ora sem objeto real, ora sem condição subjetiva de isenção” - os teóricos tributários dessa abordagem "só praticam a miudagem do que em outra parte" mostra-se "como ciência” e como efetividade, “ou seja, só vivem o simulacro e a decadência, sem nunca ter experimentado o ascenso" tecnológico das tendências de desenvolvimento da economia mundial, "situados que sempre estiveram em momentos de sociabilidade adversos". As palavras duras não se voltam prioritariamente aos agentes da pretensa cientificidade, mas com mais veemência às condições subalternas bem características de um país de economia periférica e desenvolvimento tecnológico escasso.

No caso brasileiro nossos cientistas sem objeto assistem ao recrudescimento das formas arcaicas do processo produtivo, sua atualização na realidade econômica do país e tão somente avistam ao longe a vanguarda do processo produtivo mundial. Daí decorre, a nosso ver, a persistência em descrever e denunciar o que já é fato, a precarização. 
Terminam por universalizar o fenômeno - sem dúvida mundial - como tendência geral do processo de acumulação, deixando de lado o problema de qual é efetivamente a linha tendencial que favorece o processo de acumulação do capitalismo do século XXI. As formas arcaicas coexistem com os modos mais avançados, podem perdurar por períodos consideráveis, e inclusive podem se constituir como a forma única em determinados rincões do mundo. O risco está em perder-se no ciclo transitório das formas circunscritas de realização, oriundas quase sempre de tendências particulares, de condicionantes efêmeras que prevalecem por certos períodos e em certos lugares, que não formam, no entanto, a linha preponderante das tendências em curso. Ater-se ao fenômeno e universalizá-lo significa negligenciar a riqueza de determinações da própria realidade.

Nesse sentido, a exemplaridade científica do modo investigação de Marx, ainda tem muito a nos ensinar. Não basta a propensão subjetiva para conhecer, é preciso que a realidade tenha alcançado o ponto mais desenvolvido de realização do processo em curso. Apenas com a maturação da objetividade pode o esforço intelectual humano estar apto a compreender de maneira efetiva o curso da dinâmica predominante em dadas épocas. Nesse sentido, devemos acrescentar o fato de as transformações de nossos dias serem ainda acontecimentos muito recentes. Toda a gama de possibilidades que parece estar posta no horizonte não permitem ainda constatar com clareza os rumos efetivos que se encontram em curso e quais se tornarão concretos em um futuro próximo. Isso pode justificar também a escassez de literatura em torno das transformações do trabalho nesse plano específico dos trabalhadores vinculados aos setores de alta tecnologia. $O$ decurso e as consequências da dinâmica econômica contemporânea apenas efetuam seus primeiros passos rumo à, quem sabe, uma nova conformação do processo de acumulação capitalista.

Tal condição não nos exime da tarefa de investigar em detalhes as formas concretas atuais, de procedermos a análise rigorosa das tendências que se colocam em nossos dias e vislumbrar dentro do campo de possibilidades, alternativas que nos direcionem a uma crítica eficaz da sociabilidade do capital - e somente a partir daí fazer o apontamento de caminhos. Repetir jargões, emoldurar a realidade nos limites de uma compreensão crítica simplificadora, pode servir muito bem para o âmbito da programática tática da política partidária, mas não é suficiente para apresentar possibilidades concretas de transformação social. Que nos seja permitido retomar uma famosa frase de Marx: "Os filósofos apenas interpretaram o mundo de diferentes maneiras; o que importa é transformá-lo" (MARX, 2007, p. 535), mas é preciso acrescentar: para 
transformá-lo é preciso compreendê-lo. O capolavoro de Marx, O capital, é a prova efetiva desta necessidade - compreender o mundo para transformá-lo. Não por acaso, foi a partir desse livro que iniciamos nosso questionamento ao famigerado conceito de "modo de acumulação fordistataylorista”. Dadas as condições adversas da sociabilidade de nossos tempos somente poderíamos terminar esse texto dizendo: na crítica à sociabilidade do capital, as palavras fáceis e os maneirismos intelectuais não servem de grande coisa, portanto, o rigor não é uma opção.

\section{Referências bibliográficas}

AGLIETA, Michel. Regulación y crisis del capitalismo. 6. ed. Trad. Juan Bueno. Ciudad del Mexico: Siglo XXI, 1999.

BRAVERMANN, Harry. Trabalho e capital monopolista: a degradação do trabalho no século XX. Trad. Nathanael C. Caixeto. Rio de Janeiro: Editora Guanabara, 1987.

BRENNER, Robert. The economics of global turbulence: the advanced capitalist economies from long boom do long downturn, 1945-2005. London/New York: Verso, 2006.

BRENNER, Robert; GLICK, M. The regulation approach to the history of capitalism. Économie et société, Série "Théories de la Régulation", n. 11, pp. 89-131, 1989.

CHANDLER, Alfred. Strategy and structure: chapters in the history of the American industrial enterprise. 4. ed. Cambridge: The MIT Press, 1973.

. The visible hand: managerial revolution in American business.

Massachusetts: Harvard University Press, 1977.

. O século eletrônico. Trad. Adriana Rieche. Rio de Janeiro:

Editora Campus, 2002

; HIKINO, Takashi. Scale and scope: the dynamics of industrial capitalism. Cambridge: Belknap Press, 1990.

CHASIN, José. Marx: estatuto ontológico e resolução metodológica. São Paulo: Boitempo Editorial, 2008.

CORIAT, Benjamín. El taller y el cronometro. Trad. Juan Miguel Figueroa Péres. México: Siglo XXI, 1982.

. Science, technique et capital. Paris : Seuil, 1976.

DOBB, Maurice. Economia política e capitalismo: ensaios sobre a tradição econômica. Trad. Hildete Hermes de Araujo. Rio de Janeiro: Graal, 1978.

DUHIGG, Charles; BRAKSHER, Keith. How the US lost out on iPhone work. The New York Times, 21, jan. 2012.

DUMÉNIL, Gerard ; LÉVY, Dominique. Les regulationnistes pouvaient-ils apprendre davantage des classique? Une analyse critique de quatre modèles. Paris: CEPREMAP, october, 1991. 
FORTES, Ronaldo. Sobre o conceito de exército industrial de reserva: aspectos históricos e atualidade. Temporalis, Brasília (DF), ano 18, n. 36, pp. 256-273, jul./dez. 2018.

GOUNET, Thomas. Fordismo e toyotismo na civilização do automóvel. Trad. Bernardo Joffily. São Paulo: Boitempo Editorial, 2002.

HOBSON, John. A evolução do capitalismo moderno: um estudo da produção mecanizada. Trad. Benedicto de Carvalho. São Paulo: Abril Cultural, 1985 .

- The Evolution of modern capitalism: a study of machine production. London: Walter Scott, 1897.

LANDES, David. Prometeu desacorrentado: transformação tecnológica e desenvolvimento industrial na Europa Ocidental, de 1750 até os dias de hoje. Trad. Marisa Motta. Rio de Janeiro: Ed. Elsevier, 2005.

LEMOINE, Françoise. L'économie chinoise. Paris: La Découverte, 2003.

LIPIETZ, Alain. La mondialisation de la crise générale du Fordisme. Les Temps Modernes, nr. 459, pp. 696- 736, 1984.

MANDEL, Ernest. Long waves of capitalist development: a Marxist interpretation. London: Verso, 1995.

MARX, Karl. O capital, Livro 1: O processo de produção do capital. Trad. Rubens Enderle. São Paulo: Boitempo Editorial, 2013.

; ENGELS, Friedrich. A ideologia alemã. Trad. Rubens Enderle, Nélio Schneider, Luciano Cavini Martorano. São Paulo: Boitempo, 2007.

MENSCH, Gerard. Das technologische Patt: Inovationen überwinden die Depression. Frankfurt: Umschau Verlag, 1975.

MORAES NETO, Benedito Rodrigues. Marx, Taylor, Ford: as forças produtivas em discussão. São Paulo: Editora Brasiliense, 1991.

NABUCO, Paula. As 'recentes' greves na China. Revista Outubro, n. 20, $1^{\circ}$ semestre 2012.

SEGAL Adam. When China Rules the Web, Technology in Service of the State. Foreign Affairs, September/October, 2018.

TEIXEIRA, Aloísio. Estados Unidos: a curta marcha para a hegemonia. In: FIORI, José Luís. Estado e moedas no desenvolvimento das nações. Petrópolis: Vozes, 1999.

Como citar:

FORTES, Ronaldo Vielmi. Limites e equívocos do conceito de acumulação fordista: desenvolvimento das forças produtivas e perpetuação das formas de produção arcaicas. Verinotio - Revista on-line de Filosofia e Ciências Humanas, Rio das Ostras, v. 25, n. 1, pp. 58-87, abr. 2019.

Data de envio: 15 fev. 2019 Data de aceite: 21 mar. 2019 